JEMAP : Jurnal Ekonomi, Manajemen, Akuntansi dan Perpajakan

\title{
Pengaruh Kepemimpinan Strategis terhadap Kinerja Agen Properti dengan moderasi Motivasi dan Pelatihan
}

\author{
Ester Minarni \\ esterminarni79@gmail.com \\ Magister Manajemen Fakultas Ekonomi Dan Bisnis \\ Universitas Katolik Soegijapranata
}

\begin{abstract}
This research about effect of strategic leadership toward property agent's performance aimed to know how big was the effect with motivation and training as moderating variabel. This study was conducted in Hore Property Office in Semarang. Population of this research were all of property agents and purposive sampling was conducted toward 75 respondents who are actively running business. Data collecting technique used survey method with questionnaire. Data analysis technique used descriptive and regression analysis with test of the difference of absolute value to know moderating variable. Research result conducted showed that strategic leadership influenced positively and significantly toward agent's performance. The motivation and training varibles did not significantly influence as moderating variable. It is suggested that there should be strategic guidance for agents to maintain or increase their performances. Motivating and training effort should be developed with variation of technics and activities so becomes fruitful and hands on skill for agents.
\end{abstract}

Keywords: strategic leadership, motivation, training, performance.

\section{PENDAHULUAN}

Properti merupakan kebutuhan dasar manusia sebagai bagian dari kebutuhan atas sandang dan papan. Terlibat dalam industri properti tersebut adalah antara lain pengembang (developer), investor, konsultan, notaris / PPAT, bank, penilai properti dan perantara jual-beli-sewa properti (broker properti). Tantangan untuk menyiapkan broker / agen properti yang profesional yang memiliki standar kerja yang baik, kemampuan melayani konsumen yang benar dan pengetahuan properti yang baik sangat di butuhkan. 
JEMAP : Jurnal Ekonomi, Manajemen, Akuntansi dan Perpajakan ISSN : 2622-612X (Media Online) | Vol. 2 | No. 1 | April 2019

Kantor HORE Properti adalah kantor broker properti yang memfasilitasi setiap individu yang mau berkecimpung di dunia brokerage property untuk menjadi agen properti sesuai dengan PERMENDAG no.51/M-DAG/PER/7/2017.

Kepemimpinan strategis diberlakukan ketika mereka berpikir, bertindak, dan berpengaruh dengan cara yang mempromosikan keunggulan kompetitif yang berkelanjutan bagi organisasi / perusahaan. Fokus kepemimpinan strategis adalah keuntungan kompetitif yang berkelanjutan, atau untuk keberhasilan abadi organisasi. Kepemimpinan strategis mendorong dan menggerakkan organisasi / perusahaan sehingga akan berkembang dalam jangka panjang. (Hughes dan Beatty, 2005).

\section{TINJAUAN PUSTAKA}

\section{Kepemimpinan Strategis}

Individu dan tim memberlakukan kepemimpinan strategis ketika mereka berpikir, bertindak, dan pengaruh dengan cara yang mempromosikan keunggulan kompetitif yang berkelanjutan bagi organisasi. Fokus kepemimpinan strategis adalah keunggulan kompetitif yang berkelanjutan, atau keberhasilan abadi organisasi (Hughes dan Beatty, 2005). Kepemimpinan strategis adalah tentang kemampuan seorang pemimpin mengubah orang melalui visi dan nilai-nilai, budaya dan iklim kerja, serta struktur dan sistem. Dalam hal ini kepemimpinan strategis lebih berarti kemampuan pemimpin untuk mengelola, mengkoordinasikan, memengaruhi serta memotivasi dan meningkatkan kinerja orang-orang yang dipimpinnya untuk mencapai tujuan organisasi.

Elemen Berpikir Strategis antara lain berisikan tentang System Perspective, berpikir strategis dibangun di atas dasar pandangan sistem. Bertindak Strategis antara lain sebagai berikut : sebagai motivator, dengan menetapkan prioritas yang jelas. sebagai fasilitator, pemimpin strategis memiliki keberanian untuk keyakinan tim dalam perusahaan. (Hughes dan Beatty, 2005: 86). Bagaimana caranya mempengaruhi secara adalah dengan mampu menimbulkan kepercayaan dan mengubah sikap perilaku dengan style sesuai yang dipimpin.

\section{Motivasi}


JEMAP : Jurnal Ekonomi, Manajemen, Akuntansi dan Perpajakan

Motivasi merupakan kegiatan yang mengakibatkan, menyalurkan, dan memelihara perilaku manusia. (Handoko, 2011). Teori - teori motivasi dapat diklasifikasikan menjadi tiga kelompok - petunjuk, isi dan proses. Teori - teori petunjuk (prescriptive theories) mengemukakan bagaimana memotivasi para karyawan. Teori - teori isi (content theories), disebut juga teori - teori kebutuhan (need theories), adalah berkenaan dengan pertanyaan apa penyebab - penyebab perilaku atau memusatkan pada pertanyaan " apa " dari motivasi. Teori - teori yang sangat terkenal diantaranya : hirarki kebutuhan dari psikolog Abraham H. Maslow, Frederick Herzberg dengan teori motivasi - pemeliharaan atau motivasi - higienis, dan teori prestasi dari David McClelland.

Teori - teori proses (process theories) berkenaan dengan bagaimana perilaku dimulai dan dilaksanakan atau menjelaskan aspek " bagaimana " dari motivasi. Teori - teori yang termasuk kategori teori-teori proses adalah teori pengharapan, pembentukan perilaku (operant conditioning), teori Porter - Lawler, dan teori keadilan.

Dari beberapa teori motivasi tersebut diatas, maka teori yang dipakai dalam penelitian ini adalah teori motivasi - Higiene dari Herzberg yang merupakan pengembangan dari teori hirarki kebutuhan menurut Maslow. Teori Herzberg memberikan dua kontribusi penting bagi pimpinan organisasi dalam memotivasi karyawan. Pertama, teori ini lebih eksplisit dari teori hierarki kebutuhan Maslow, khususnya mengenai hubungan antara kebutuhan dalam performa pekerjaan. Kedua, kerangka ini membangkitkan model aplikasi, pemerkayaan pekerjaan (Sumantri, 2012; Handoko, 2011).

Teori Herzberg ini melihat ada dua faktor yang mendorong karyawan termotivasi yaitu faktor intrinsik, merupakan daya dorong yang timbul dari dalam diri masing-masing orang, dan faktor ekstrinsik yaitu daya dorong yang datang dari luar diri seseorang, terutama dari organisasi tempatnya bekerja (Hasibuan, 2005; Handoko, 2011). Herzberg mengemukakan (Arep dan Tanjung 2004) bahwa kepuasan manusia terdiri atas dua hal, yaitu puas dan tidak puas. Selanjutnya Pittsburg (Arep, dkk 2004:28) melakukan studi yang kemudian melahirkan Teori Two Factor, dalam teori ini terdapat beberapa faktor yang menimbulkan 
JEMAP : Jurnal Ekonomi, Manajemen, Akuntansi dan Perpajakan ISSN : 2622-612X (Media Online) | Vol. 2 | No. 1 | April 2019

ketidakpuasan dan yang menimbulkan kepuasan. Oleh karena itu, untuk mengingkatkan motivasi maka manajer harus proaktif menghilangkan rasa ketidak puasan.

\section{Pelatihan}

Pelatihan didefinisikan oleh Ivancevich sebagai usaha untuk meningkatkan kinerja karyawan dalam pekerjaannya sekarang atau dalam pekerjaan lain yang akan diberikan kepadanya. Pelatihan terkait dengan ketrampilan dan kemampuan yang diperlukan untuk pekerjaan yang sekarang dilakukan (Sutrisno, 2009). Pembelajaran bagi komunitas organisasi / perusahaan dikenal dalam satu bentuk yang disebut sebagai pelatihan (training). Dapat diklasifikasikan bahwa perubahan manajemen organisasi dalam segala bentuk pemenuhan skills, knowledge dan ability dilakukan melalui proses pembelajaran.

Pelatihan merupakan proses pendidikan jangka pendek yang menggunakan prosedur sistematis dan terorganisasi, yang mana tenaga kerja nonmanajerial mempelajari pengetahuan dan ketrampilan teknis untuk tujuan - tujuan tertentu. Pelatihan menyangkut usaha - usaha yang berencana yang diselenggarakan agar dicapai penguasaan akan ketrampilan, pengetahuan, dan sikap-sikap yang relevan terhadap pekerjaan (Sutrisno, 2009).

\section{Kinerja}

Pengertian manajemen kinerja menurut Udekusuma (2007), manajemen kinerja adalah suatu proses manajemen yang dirancang untuk menghubungkan tujuan organisasi dengan tujuan individu sedemikian rupa, sehingga baik tujuan individu maupun tujuan perusahaan dapat bertemu.

Baron dan Greenberg (1990) dalam Thoyib (2005:10) mengemukakan bahwa kinerja pada individu juga disebut dengan job performance, work outcomes, task performance. Brahmasari (2004:64) mengemukakan bahwa kinerja adalah pencapaian atas tujuan organisasi yang dapat berbentuk output kuantitatif maupun kualitatif, kreatifitas, fleksibilitas, dapat diandalkan, atau hal-hal lain yang diinginkan oleh organisasi. Tika ( 2006:121 ) mengemukakan bahwa ada empat unsur-unsur yang. terdapat dalam kinerja adalah hasil - hasil fungsi pekerjaan, 
JEMAP : Jurnal Ekonomi, Manajemen, Akuntansi dan Perpajakan

faktor - faktor yang berpengaruh terhadap prestasi karyawan, pencapaian tujuan organisasi, dan periode waktu tertentu

\section{Penelitian Terdahulu}

Penelitian yang dilakukan oleh RL Hughes, KC Beatty, 2005. Penelitian yang dilakukan dengan variabel berpikir strategis, bertindak strategis, pengaruh strategis dengan variabel penelitian yang berada di dalam penelitian yang dilakukan. Penelitian yang dilakukan oleh Paul J.H. Schoemaker, 1995. Penelitian yang dilakukan dengan variabel driver perubahan, tren dasar, ketidakpastian kunci, interaksi, skenario berganda dengan variabel penelitian yang berbeda dari yang berbeda dari penelitian yang dilakukan peneliti serta penggunaan metode penelitian yang berbeda pula.

Penelitian yang dilakukan oleh Stefanos Mouzas, 2001. Penelitian yang dilakukan dengan variabel yang memicu aksi strategis, mendapatkan wawasan baru ke jaringan pengecer pabrikan dengan variabel penelitian yang berbeda dari penelitian yang dilakukan peneliti serta penggunaan metode penelitian yang berbeda. Penelitian yang dilakukan oleh Gustave Iskandar, 2015. Penelitian yang dilakukan dengan variabel kepemimpinan strategis, motivasi, pelatihan, kinerja distributor dengan variabel penelitian yang sama di dalam penelitian yang dilakukan peneliti, penggunaan metode penelitian. Kepemimpinan strategis distributor berpengaruh positif terhadap kinerja distributor Stokis High Desert Semarang dengan motivasi sebagai variabel moderating. Kepemimpinan strategis distributor berpengaruh positif terhadap kinerja distributor Stokis High Desert Semarang dengan pelatihan sebagai variabel moderating.

\section{Kerangka Pikir}

Berdasarkan telaah pada tinjauan pustaka diatas, selanjutnya disusun sebuah kerangka pikir yang secara diagramatis menggambarkan alur pemikiran yang dikembangkan dalam penelitian ini. 


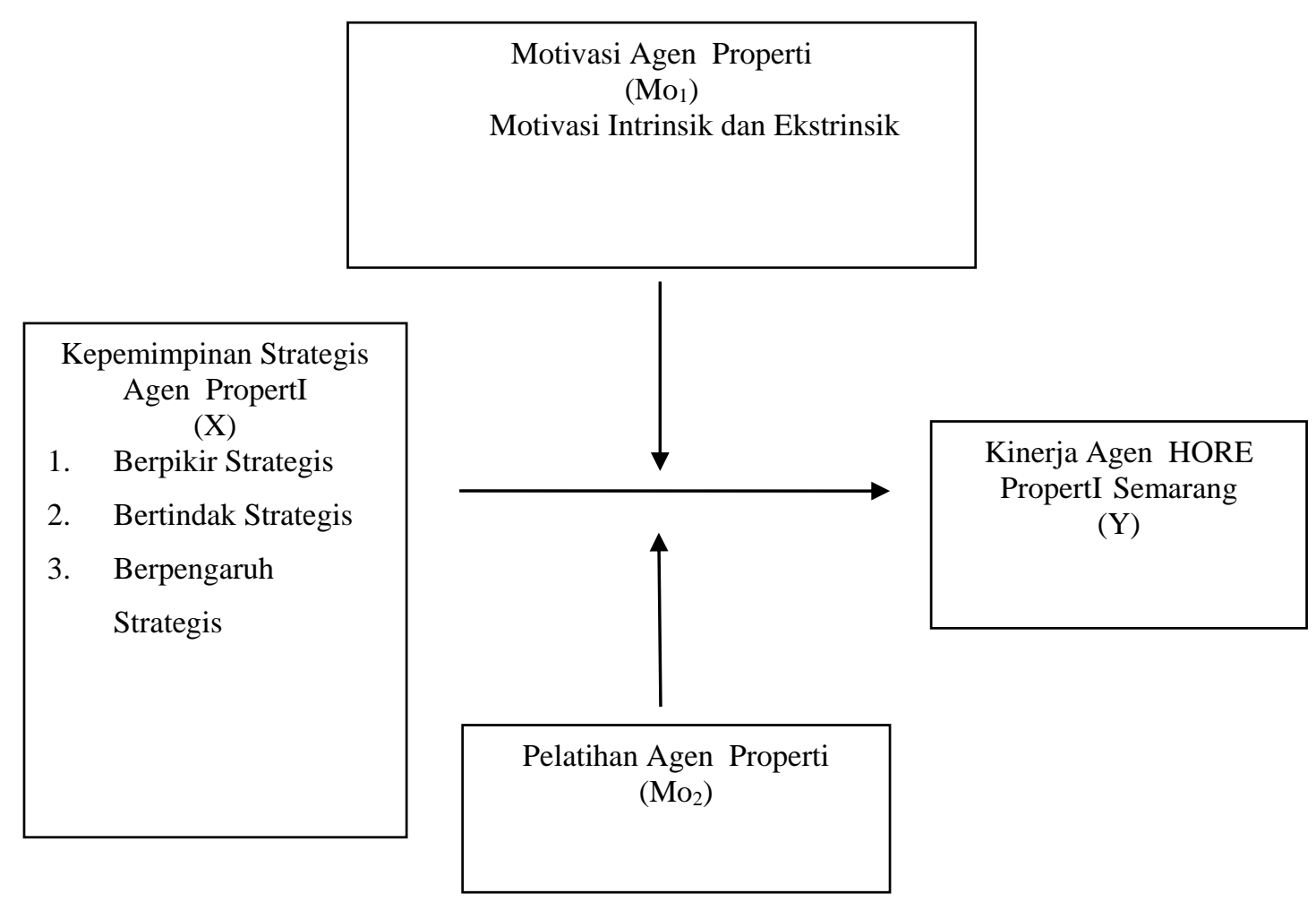

Gambar 1. Kerangka Pemikiran Teoritis

Secara garis besar, kerangka pemikiran teoritis penelitian ini menjelaskan hubungan langsung antara variabel - variabel independen kepemimpinan strategis dan dengan variabel dependen kinerja agen Properti .

\section{Hipotesis}

Hipotesis merupakan dugaan terhadap keadaan variabel mandiri, perbandingan keadaan variabel pada berbagai sampel, dan merupakan dugaan tentang hubungan antara dua variabel atau lebih. Maka berdasarkan model kepemimpinan strategis, hipotesis penelitian adalah sebagai berikut :

$\mathrm{H}_{1}$ : Kepemimpinan strategis agen properti berpengaruh positif terhadap kinerja agen Properti.

$\mathrm{H}_{2}$ : Motivasi agen properti berpengaruh positif terhadap kinerja agen Properti.

$\mathrm{H}_{3}$ : Pelatihan agen properti berpengaruh positif terhadap kinerja agen HORE Properti Semarang. 
$\mathrm{H}_{4}$ : Kepemimpinan strategis agen properti berpengaruh positif terhadap kinerja agen Properti dengan motivasi sebagai variabel moderating.

$\mathrm{H}_{5}$ : Kepemimpinan strategis agen properti berpengaruh positif terhadap kinerja agen Properti dengan pelatihan sebagai variabel moderating.

\section{Definisi Operasional Variabel Penelitian}

Kepemimpinan Strategis. Dalam penelitian ini yang dimaksud dengan kepemimpinan strategis adalah kompetensi kepemimpinan agen Properti yang diperlukan pada pengembangan bisnis Propertinya, memberlakukan kepemimpinan strategis ketika mereka berpikir, bertindak, dan memberikan pengaruh bagi rekan kerjanya (partner yang diajak bekerja sama) untuk perkembangan kinerja bisnis Propertinya. Fokus kepemimpinan strategis agen Properti adalah keunggulan kompetitif yang berkelanjutan untuk keberhasilannya di bisnis Properti.

Motivasi (Variabel Moderasi $1=$ Mo). Motivasi adalah suatu dorongan kehendak seorang agen Properti, yang menyebabkan orang melakukan suatu perbuatan untuk mencapai tujuan tertentu. Motivasi yang timbul dari dalam diri agen Properti untuk mau menjalankan bisnis Properti dapat membantu dirinya untuk menjalankan bisnis Properti. Juga kemampuan agen Properti untuk menumbuhkan motivasi bagi rekan kerjanya dapat membantu perkembangan bisnis Propertinya. Motivasi ini menjadi moderasi Properti untuk mengembangkan Bisnis Propertinya.

Pelatihan (Variabel Moderasi $2=\mathbf{P}$ ). Pelatihan adalah suatu proses dimana orang - orang mencapai kemampuan tertentu untuk membantu mencapai tujuan organisasi. Pelatihan yang dimaksud dalam hal ini ditujukan untuk agen Properti. Agen Properti mendapatkan pelatihan dari tahap awal yaitu training dasar sampai tahap pemimpin (Leader) sesuai dengan prestasi yang diraih di bisnis Propertinya. Pelatihan ini menjadi moderasi Properti untuk mengembangkan bisnis Propertinya.

Kinerja Agen (Variabel Dependen = Y).

Kinerja yang dimaksud dalam penelitian ini adalah hasil kerja secara kualitas dan kuantitas yang dicapai oleh seorang agen Properti dalam melaksanakan tugasnya sesuai dengan tanggung jawab yang diberikan kepadanya. Dalam 
JEMAP : Jurnal Ekonomi, Manajemen, Akuntansi dan Perpajakan

mengukur kinerja agen Properti dengan mengukur rata - rata revenue agen Properti per bulan selama 6 bulan, dimana revenue terendah adalah dibawah 5.000.000 rupiah per bulan mendapatkan skor 1 untuk sangat kurang, revenue antara 5.000.000 - 10.000.000 rupiah per bulan mendapatkan skor 2 untuk kurang, revenue antara 10.000.000 - 20.000.000 rupiah per bulan mendapatkan skor 3 untuk cukup, revenue antara 20.000.000 - 30.000.000 rupiah per bulan mendapatkan skor 4 untuk baik dan revenue tertinggi adalah diatas 30.000.000 rupiah per bulan mendapatkan skor 5 untuk baik sekali.

\section{METODE PENELITIAN}

Obyek pada penelitian ini adalah agen HORE Properti Semarang yang aktif dan terdaftar. Peneliti berasumsi bahwa responden sudah mengerti bagaimana mengembangkan bisnis agen Properti secara keseluruhan sehingga diharapkan dapat memberikan data yang valid dalam mengisi kuesioner nantinya. Pada penelitian ini digunakan metode survei dengan personal intercept, dimana peneliti melakukan penyebaran kuesioner kepada responden yang kebetulan berada di kantor HORE Properti Semarang. Peneliti berasumsi bahwa data yang dimasukkan oleh pengguna valid. Dalam penelitian ini yang menjadi populasi adalah agen HORE Properti Semarang yang aktif dan terdaftar di HORE Properti Semarang sejumlah 300 agen HORE Properti Semarang .

Pengambilan sampel dilakukan dengan metode proportional sampling untuk setiap agen HORE Properti Semarang yang aktif dan terdaftar di kantor HORE Properti Semarang. Sampel adalah bagian dari jumlah dan karakteristik yang dimiliki oleh populasi tersebut (Sugiyono, 2013). Peneliti menggunakan teknik nonprobability sampling, dimana teknik pengambilan sampelnya tidak memberi peluang / kesempatan sama bagi setiap unsur atau anggota populasi untuk dipilih menjadi sampel. Teknik sampling yang digunakan adalah sampling purposive, dimana teknik penentuan sampel dengan pertimbangan tertentu. (Sugiyono, 2013).

Jumlah sampel yang di teliti ditentukan dengan menggunakan rumus Slovin dengan kesalahan pengambilan sampel yang paling efektif atau paling besar adalah sebesar $10 \%$, sehingga tingkat kepercayaan mencapai 90\%. Didapat besar sampel 
JEMAP : Jurnal Ekonomi, Manajemen, Akuntansi dan Perpajakan ISSN : 2622-612X (Media Online) | Vol. 2 | No. 1 | April 2019

$\mathrm{n}=75$ orang (angka minimal). Sampel yang diambil adalah agen HORE Properti Semarang yang memenuhi kriteria sebagai berikut : Mengumpulkan minimal 10 listing properti dalam sebulan; Membayar office sharing dan merekrut agen di bawahnya sebagai rekan kerja (downline) minimal 1 orang dalam 1 bulan; Absensi kehadiran terpenuhi, kewajiban meeting dan semua kegiatan di kantor diikuti; Memiliki semua tools marketing kantor HORE Properti Semarang untuk menjalankan bisnisnya; dan melakukan transaksi properti minimal 1 x dalam 1 bulan lewat kantor HORE Properti Semarang.

Teknik pengumpulan data pada penelitian ini menggunakan kuesioner yang dibagikan kepada responden. Dalam penelitian ini kuesioner diberikan kepada responden yang ada di kantor HORE Properti Semarang, yaitu agen properti yang aktif menjalankan bisnis propertinya dan sudah bertransaksi Properti di HORE Properti Semarang. Teknik kuesioner dipilih dikarenakan jumlah responden yang ada di Semarang dan diharapkan nantinya proses pengumpulan data menjadi lebih cepat dan analisis data menjadi lebih mudah. Hasil uji validitas memperlihatkan semua indikator dalam item kuesioner valid dan reliabel.

Analisis data dilakukan dengan statistik deskriptif dan statistik inferensial. Teknik statistik digunakan untuk menganalisis data sampel dan hasilnya diberlakukan untuk populasi. Statistik deskriptif untuk melihat kategori jawaban responden dan distribusi frekuensi. Analisis data moderasi dilakukan dengan Uji Nilai Selisih Mutlak (Ghozali, 2013: 223 - 244).

\section{HASIL DAN PEMBAHASAN}

Obyek penelitian ini adalah di perusahaan bisnis yang lebih dikenal dengan nama HORE Properti Indonesia, dimana HORE Properti Indonesia berpusat di kota Surabaya, dan memiliki cabang di kota Jakarta, Semarang dan Makassar. Di kota Semarang, HORE Properti dirintis sejak tahun 2009, dan HORE Properti melayani jual, beli, sewa properti di kota - kota di seluruh Jawa Tengah. Adapun lokasi penelitian ini adalah HORE Properti Semarang di Jl. Rukan Mutiara Marina Kav. 35 - 36, Semarang, Jawa Tengah. 
Responden pada penelitian ini berpendidikan Sarjana ada 31 orang atau 41,33 $\%$ dan memiliki pekerjaan sebagai Wiraswasta ada 35 orang atau 46,67 \%. Menggambarkan bahwa responden yang berpendidikan Sarjana dan berwiraswasta, mempunyai bisnis lain selain aktif sebagai agen HORE Properti Semarang, lebih mendominasi di kantor HORE Properti Semarang.

Responden pada penelitian ini aktif menjalankan bisnis agen HORE Properti dalam waktu kurang dari 5 tahun ada 40 orang atau 53,33\%, dan mayoritas responden masih menjalankan Bisnis agen HORE Properti masih sekitar 3-6 bulan. Yang memiliki klasifikasi Kelas Advance di agen HORE Properti ada 23 orang atau $30,67 \%$.

\section{Pengaruh kepemimpinan strategis agen HORE Properti Semarang terhadap kinerja agen HORE Properti Semarang}

Pengujian hipotesis pertama dilakukan untuk mengetahui pengaruh kepemimpinan strategis agen HORE Properti Semarang terhadap kinerja agen HORE Properti Semarang dengan hasil sebagai berikut : Dari tampilan output SPSS model summary besarnya adjusted $\mathrm{R}^{2}$ adalah 0,190 , hal ini berarti $19,0 \%$ variasi kinerja agen HORE Properti Semarang dapat dijelaskan oleh variasi dari variabel independen kepemimpinan strategis agen HORE Properti Semarang. Sedangkan sisanya $(100 \%-19,0 \%=81 \%)$ dijelaskan oleh sebab - sebab yang lain diluar model. Penelitian ini mendukung penelitian yang dilakukan oleh RL Hughes, KC Beatty (2005), kepemimpinan strategis agen HORE Properti Semarang secara aktif mendukung pertumbuhan dan perkembangan, semakin maju kepemimpinan strategis agen HORE Properti Semarang akan mendukung peningkatan kinerja agen HORE Properti Semarang. Para anggota tim memiliki kepemimpinan strategis berinteraksi yang konstruktif, memotivasi orang lain di seluruh organisasi.. Standar Error of Estimate (SEE) sebesar 1,15821 per bulan. Makin kecil nilai SEE akan membuat model regresi semakin tepat dalam memprediksi variabel independen. (Ghozali, 2013:100)

Pengaruh motivasi agen HORE Properti Semarang terhadap kinerja agen HORE Properti Semarang 
JEMAP : Jurnal Ekonomi, Manajemen, Akuntansi dan Perpajakan

Pengujian hipotesis kedua dilakukan untuk mengetahui pengaruh motivasi agen HORE Properti Semarang terhadap kinerja agen HORE Properti Semarang dengan hasil sebagai berikut : Dari tampilan output SPSS model summary besarnya adjusted $\mathrm{R}^{2}$ adalah 0,160, hal ini berarti 16,0 \% variasi kinerja agen HORE Properti Semarang dapat dijelaskan oleh variasi dari variabel independen motivasi agen HORE Properti Semarang. Sedangkan sisanya $(100 \%-16,0 \%=84 \%)$ dijelaskan oleh sebab - sebab yang lain diluar model. Standar Error of Estimate (SEE) sebesar 1,39855 per bulan. Makin kecil nilai SEE akan membuat model regresi semakin tepat dalam memprediksi variabel independen. (Ghozali, 2013:100). Unstandardized beta coefficients : Motivasi tidak signifikan, hal ini dapat dilihat dari probabilitas signifikansi untuk motivasi sebesar 0.140, jauh di atas 0,05. Jadi hipotesis kedua ditolak, tidak terdapat pengaruh langsung antara motivasi agen HORE Properti Semarang terhadap kinerja agen HORE Properti Semarang.

\section{Pengaruh pelatihan agen HORE Properti Semarang terhadap kinerja agen HORE Properti Semarang}

Pengujian hipotesis ketiga dilakukan untuk mengetahui pengaruh pelatihan agen HORE Properti Semarang terhadap kinerja agen HORE Properti Semarang dengan hasil sebagai berikut : Dari tampilan output SPSS model summary besarnya adjusted $\mathrm{R}^{2}$ adalah 0,013 , hal ini berarti $1,3 \%$ variasi kinerja agen HORE Properti Semarang dapat dijelaskan oleh variasi dari variabel independen pelatihan agen HORE Properti Semarang. Sedangkan sisanya $(100 \%-1,3 \%=98.7 \%)$ dijelaskan oleh sebab - sebab yang lain diluar model. Standar Error of Estimate (SEE) sebesar 1,40087 per bulan. Makin kecil nilai SEE akan membuat model regresi semakin tepat dalam memprediksi variabel independen. (Ghozali, 2013:100). Unstandardized beta coefficients : Pelatihan tidak signifikan, hal ini dapat dilihat dari probabilitas signifikansi untuk pelatihan sebesar 1,164 jauh di atas 0,05. Jadi hipotesis ketiga ditolak, tidak terdapat pengaruh positif antara pelatihan agen Properti terhadap kinerja agen Properti. 
JEMAP : Jurnal Ekonomi, Manajemen, Akuntansi dan Perpajakan

ISSN : 2622-612X (Media Online) | Vol. 2 | No. 1 | April 2019

Pengaruh kepemimpinan strategis terhadap kinerja agen HORE Properti Semarang dengan motivasi sebagai variabel moderating.

Pengujian hipotesis keempat dilakukan untuk mengetahui pengaruh kepemimpinan strategis terhadap kinerja agen Properti dengan motivasi sebagai variabel moderating, dengan hasil sebagai berikut : Tampilan output SPSS menunjukkan nilai Adjusted $\mathrm{R}^{2}$ 18,3\% yang berarti variabilitas kinerja agen HORE Properti Semarang yang dapat dijelaskan oleh variabel Zkepemimpinan strategis, Zmotivasi dan Absx_mo sekitar 18,3\% dan sisanya 81,7 \% dijelaskan oleh variabel lain diluar model ini.

Hasil Anova atau F test menunjukkan bahwa nilai F hitung sebesar 12,620 dengan tingkat signifikansi 0,000 jauh di bawah 0,05. Hal ini berarti bahwa variabel independen Zkepemimpinan strategis, Zmotivasi dan Absx_mo secara bersama sama atau simultan mempengaruhi kinerja agen HORE Properti Semarang.

Hasil tampilan output SPSS jelas menunjukkan bahwa secara individu variabel Zkepemimpinan strategis memberikan nilai koefisien 0.591 dengan probabilitas signifikansi 0,000. Variabel Zmotivasi memberikan nilai koefisien 0,13 dengan probabilitas signifikansi 0,911, jauh di atas 0,05 . Variabel moderating AbsKepemimpinanStrategis_Movitasi ternyata tidak signifikan yaitu dengan probabilitas signifikansi 0,072 dan di atas 0,05. Temuan ini menunjukkan bahwa variabel motivasi tidak memoderasi hubungan kepemimpinan strategis terhadap kinerja. (Ghozali, 2013 : 239). Jadi hipotesis keempat ini ditolak, motivasi tidak memoderasi hubungan kepemimpinan strategis terhadap kinerja. Dari data responden yang sebagian besar agen baru dan bekerja sebagai wiraswasta, maka bisa dipahami bahwa di sini motivasi belum berpengaruh secara signifikan.

\section{Pengaruh kepemimpinan strategis terhadap kinerja agen HORE Properti Semarang dengan pelatihan sebagai variabel moderating.}

Pengujian hipotesis kelima dilakukan untuk mengetahui pengaruh kepemimpinan strategis terhadap kinerja agen HORE Properti Semarang dengan pelatihan sebagai variabel moderating, dengan hasil sebagai berikut : Tampilan output SPSS menunjukkan nilai Adjusted $\mathrm{R}^{2}$ 17,7 \% yang berarti variabilitas kinerja 
JEMAP : Jurnal Ekonomi, Manajemen, Akuntansi dan Perpajakan ISSN : 2622-612X (Media Online) | Vol. 2 | No. 1 | April 2019

agen HORE Properti Semarang yang dapat dijelaskan oleh variabel Zkepemimpinan strategis, Zpelatihan dan Absx_p sekitar 17,7 \% dan sisanya 82,30 $\%$ dijelaskan oleh variabel lain di luar model ini.

Hasil Anova atau F test menunjukkan bahwa nilai F hitung sebesar 8,406 dengan tingkat signifikansi 0,000 jauh di bawah 0,05. Hal ini berarti bahwa variabel independen Zkepemimpinan strategis, Zpelatihan dan Absx_p secara bersama sama atau simultan mempengaruhi kinerja agen HORE Properti Semarang.

Hasil tampilan output SPSS jelas menunjukkan bahwa secara individu variabel Zkepemimpinan strategis memberikan nilai koefisien 0,572 dengan probabilitas signifikansi 0,000. Variabel Zpelatihan memberikan nilai koefisien 0,029 dengan probabilitas signifikansi 0,805, jauh di atas 0,05. Koefisien Variabel moderating Interaksi P 0,070 ternyata juga tidak signifikan yaitu dengan probabilitas signifikansi 0,636 dan di atas 0,05. Temuan ini menunjukkan bahwa variabel pelatihan tidak memoderasi hubungan kepemimpinan strategis terhadap kinerja. (Ghozali, 2013 : 239). Jadi hipotesis 5 ditolak, pelatihan tidak memoderasi hubungan kepemimpinan strategis terhadap kinerja. Dari data responden yang sebagian besar masih beginner, maka bisa dipahami mereka kurang pelatihan sehingga tidak mempengaruhi kinerja agen properti ini terjadi.

\section{Implikasi Manajerial}

Untuk mengetahui bagaimana implikasi manajerial pengaruh kepemimpinan strategis agen Properti terhadap kinerja dengan moderasi motivasi dan pelatihan, mayoritas reponden masih menjalankan bisnis agen HORE Properti Semarang sekitar $3-6$ bulan. Berarti dibutuhkan banyak waktu untuk dimotivasi, mengikuti pelatihan - pelatihan untuk mengembangkan agen. Responden pada penelitian ini lebih banyak berjenis kelamin wanita yang masih ada di usia produktif yaitu usia 33 - 46 tahun dan lebih banyak memiliki pekerjaan sebagai wiraswasta. Di masa mendatang, dapat ditingkatkan jumlah agen baru pria dan dengan sepenuh waktu (full time).

Responden lebih banyak memiliki klasifikasi kelas beginner sehingga pertumbuhan bisnis mengalami penurunan, karena kemungkinan, jarang ada 
JEMAP : Jurnal Ekonomi, Manajemen, Akuntansi dan Perpajakan

pemimpin (leader) yang fokus mengembangkan bisnis agen, masih banyak memfokuskan pekerjaannya di luar bidang Properti. Hal ini mengindikasikan bahwa mayoritas reponden masih menjalankan bisnis agen Properti masih tergolong baru. Kemungkinan belum mempunyai kapasitas sebagai seorang pemimpin. Belum punya kemampuan memecahkan masalah di bisnis agen Properti, yang dilakukan dengan mengidentifikasi poin-poin kunci masalah yang terjadi. Belum punya kemampuan memfasilitasi tindakan down line dan up line untuk dapat mengembangkan bisnis agen Properti. Dan belum punya kemampuan membangun jaringan hubungan dengan banyak orang, tidak terbuka dalam kesempatan apapun untuk berbagi, sharing dan tidak mampu mempengaruhi orang lain untuk selalu mempunyai pola pikir positif (mindset) positif dalam hidupnya.

Di masa mendatang, dapat dilakukan meningkatkan koordinasi dengan pemimpin (leader) senior, yang mempunyai klasifikasi kelas intermediate dan advance untuk mengatur jadwal secara bergantian untuk membimbing agen Properti yang masih banyak klasifikasi sebagai kelas pemula / beginner. Bekerja sama dengan para pemimpin (leader) untuk fokus mengembangkan bisnis agen Properti, serta meningkatkan kepemimpinan strategis bagi agen yang sudah bergabung dan akan direkrut nantinya. Memberikan motivasi dan pelatihan terus menerus secara rutin kepada semua agen Properti sesuai dengan level / tingkatan manajerialnya. Meningkatkan pengetahuan dan kemampuan agen dalam menjalankan bisnis agen Properti, yang pengaruhnya akan meningkatkan kinerja agen Properti.

Nilai rata-rata untuk variabel kinerja agen HORE Properti Semarang yang dinilai masih rendah, untuk masa mendatang dapat dilakukan dengan meningkatkan jumlah agen baru yang aktif. Ditingkatkan kepemimpinan strategisnya, diberikan motivasi dan pelatihan, dibantu untuk mengembangkan jaringan propertinya di kota Semarang, maka kinerja agen Properti akan dapat meningkat. Juga diperlukan peran dari pemerintah untuk memberikan perlindungan yang jelas, wadah yang jelas bagi semua agen properti untuk dapat mengerjakan bisnis propertinya dengan aman, nyaman dan menguntungkan. 
JEMAP : Jurnal Ekonomi, Manajemen, Akuntansi dan Perpajakan ISSN : 2622-612X (Media Online) | Vol. 2 | No. 1 | April 2019

\section{PENUTUP}

Kepemimpinan strategis berpengaruh langsung terhadap kinerja agen properti. Dari analisis deskriptif, kepemimpinan strategis agen termasuk kategori setuju. Motivasi agen tidak terdapat pengaruh langsung terhadap kinerja agen. Motivasi agen termasuk kategori setuju. Pelatihan tidak berpengaruh langsung terhadap kinerja. Pelatihan termasuk kategori setuju.

Kepemimpinan strategis agen properti tidak berpengaruh langsung terhadap kinerja agen dengan pelatihan sebagai variabel moderating. Variable pelatihan tidak memoderasi hubungan kepemimpinan strategis dengan variabel kinerja. Dari pengujian analisis deskriptif, pelatihan agen HORE Properti Semarang termasuk kategori setuju.

Implikasi manajerialnya adalah bisa dipertimbangkan dengan menambah jumlah agen baru yang aktif menjalankan bisnis properti, meningkatkan kepemimpinan strategisnya, memberikan motivasi dan pelatihan terus menerus secara rutin kepada semua agen sesuai dengan level / tingkatan manajerialnya, meningkatkan pengetahuan dan kemampuannya dalam menjalankan bisnis properti.

Agen properti perlu dirangsang untuk mengejar target yang ditetapkan, misalnya program jalan - jalan ke luar negri, program closing fee tambahan bagi agen dan lain lain. Bagi para pemimpin / up line, disarankan lebih mampu memotivasi, meyakinkan, membimbing, menumbuhkan dan mengembangkan para rekan kerjanya / down linenya. Dengan kenaikkan omset rekan kerjanya / down linenya, tujuan - tujuan pribadi para rekan kerjanya / down linenya akan ikut tercapai pula. Agen lebih diajarkan cara - cara memecahkan masalah bisnis yang dilakukan dengan mengidentifikasi poin - poin kunci masalah yang terjadi dengan mengikuti pelatihan yang disediakan oleh kantor dan mengikuti sertifikasi profesi sebagai agen properti. 
JEMAP : Jurnal Ekonomi, Manajemen, Akuntansi dan Perpajakan

ISSN : 2622-612X (Media Online) | Vol. 2 | No. 1 | April 2019

\section{DAFTAR PUSTAKA}

Arep, Ishak dan Hendri Tanjung. (2004). Manajemen Motivasi. Cetakan kedua. Jakarta : PT Grasindo.

Azwar, Saifuddin, 2013. Metode Penelitian. Yogyakarta : Pustaka Pelajar.

Bjoern Six, Marcel Normann, Ruth Maria Stock, Dirk Schiereck. (2013). Strategic Leaders' Impact on Corporate Policies and Firm Performance: Insights from CEO $\mathrm{s}$ and CFOs of Large Listed Firms in Germany. Diakses dari https://link.springer.com/ article/10.1007/BF03396851

Dharma Surya. (2005). Manajemen Kinerja Falsafah, Teori dan Penerapannya. Yogyakarta : Pustaka Pelajar,.

Djam'an Satori dan Aan Komariah. (2010). Metodologi Penelitian Kualitatif. Bandung : Alfabeta.

Ghozali, I. (2013). Aplikasi Analisis Multivariate dengan Program IBM SPSS 21, Update PLS Regresi. Semarang : Badan Penerbit Universitas Diponegoro.

Gustave, I. (2015). Pengaruh Kepemimpinan Strategis terhadap Kinerja dengan moderasi Motivasi dan di Stokis High Desert. Semarang : Tesis Universitas Katolik Soegijapranata. http://repository.unika.ac.id/299/

Handoko, T. Hani. (2011). Manajemen. Yogyakarta : Badan Penerbit Fakultas Ekonomi.

Hasibuan M. (2005). Manajemen Sumber Daya Manusia. Jakarta : Penerbit Bumi Aksara.

Hughes dan Beatty. (2005). "Becoming a Strategic Leader : Your Role in Your Organization's Enduring Success, Jossey-Bass A Wiley Imprint 989 Market Street, San Francisco, CA 94103-174." Diakses dari : https://leseprobe.buch.de/images-adb/88/12/88129186-f21b-4e3d-86f7f3d2b764dldd.pdf

Luh Putu Ratih Andini. (2013). "Pelatihan AMT (Achievement Motivation

Training) untuk meningkatkan motivasi berprestasi pada member perusahaan MLM, Jurnal Ilmiah Mahasiswa Universitas Surabaya Vol. 2, No. 2 (2013)". Diakses dari : http://download.portalgaruda.org/article.php? article $=147812 \& \mathrm{val}=5455 \&$ title $=$ PELATIHAN\%20AMT\%20

(ACHIEVEMENT\%MOTIVATION\%2OTRAINING)\%2OUNTUK\%20 MENINGKATKAN\%20MOTIVASI\%20BERPRESTASI\%20PADA\%20MEM BER\%2OPERUSAHAAN\%20MLM\%20(Multi\%20Level\%20Marketing)

Manuel G. Calvo and M. Dolores Castillo, and Franz Schmalhofer. (2006). "Strategic influence on the time course of predictive inferences in reading, Memory \& Cognition 2006, 34 (1), 68-77." Diakses dari : https://link.springer.com/article/ 10.3758/ BF03193387 
JEMAP : Jurnal Ekonomi, Manajemen, Akuntansi dan Perpajakan

Schoemaker, Paul J.H. (1995). "Scenario planning: a tool for strategic thinking" from Sloan Management Review 36 (2) pp.25-40, Cambridge, Mass.: Massachussetts Institute of Technology (C)." Diakses dari : http://www.ftms.edu.my/images/Document/ MOD001074\%2020Strategic\% 20Management\%20Analysis/WK4_SR_MOD001074_Schoemaker_1995.pdf

Stefanos Mouzas. (2001). "Real Mechanism of Strategic Acting, Paper prepared for the 17th IMP Conference, Norwegian School of Management BI, Oslo, September 2001, Correspondence: Stefanos Mouzas, Goltstein Str. 64, D50968 Cologne. Stefanos_Mouzas@ hotmail.com, Tel. \& Fax: 0049221 386734. ’Diakses dari : https://www.impgroup.org/uploads/papers/237.pdf

Sugiyono. (2013). Metode Penelitian Bisnis. Bandung : Alfabeta.

Sumantri S. (2012). Perilaku Organisasi. Bandung : Universitas Padjadjaran. https://www. slideshare.net/suryanasumantri/perilaku-organisasi

Sutrisno, Edy. (2009). Manajemen sumber daya manusia. Jakarta : Kencana

Thoyib Armanu. (2005). "Hubungan Kepemimpinan, Budaya, Strategi dan Kinerja: Pendekatan Konsep, Jurnal Fakultas Ekonomi Universitas Brawijaya Malang." Diakses dari : $\quad$ http://blog.ub.ac.id/senyumu/files/ 2013/11/Hubungan-Kepemimpinan-Budaya-Strategi-dan-Kinerja.pdf

Tika H. Moh. Pabundu. (2006). Budaya Organisasi dan Peningkatan Kinerja Perusahaan. PT. Jakarta : Bhumi Aksara.

Winardi, J. (2004). Motivasi dan Pemotivasian dalam Manajemen. Jakarta : Rajawali Pers. 